\title{
Critical thinking in nursing students from two Brazilian regions
}

\author{
Pensamento crítico em estudantes de Enfermagem de duas regiões brasileiras \\ Pensamiento crítico de estudiantes de Enfermería de dos regiones brasileñas
}

Diana Paula de Souza Rego Pinto Carvalho' ORCID: 0000-0001-9485-5015

Allyne Fortes Vitor' ORCID: 0000-0002-4672-2303

Ana Luísa Petersen Cogo" ORCID: 0000-0003-2168-7801

Greicy Kelly Gouveia Dias Bittencourt"I ORCID: 0000-0001-5287-8171

Viviane Euzébia Pereira Santos' ORCID: 0000-0001-8140-8320

Marcos Antonio Ferreira Júnior' ORCID: 0000-0002-9123-232X

'Universidade Federal do Rio Grande do Norte. Natal, Rio Grande do Norte, Brazil. "Universidade Federal do Rio Grande do Sul. Porto Alegre, Rio Grande do Sul, Brazil. I'" Universidade Federal da Paraíba. João Pessoa, Paraíba, Brazil.

How to cite this article: Carvalho DPSRP, Vitor AF, Cogo ALP, Bittencourt GKGD, Santos VEP, Ferreira Jr MA. Critical thinking in nursing students from two Brazilian regions.

Rev Bras Enferm. 2020;73(1):e20170742. doi: http://dx.doi.org/10.1590/0034-7167-2017-0742

Corresponding Author:

Diana Paula de Souza Rego Pinto Carvalho E-mail: diana-rego@hotmail.com

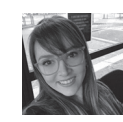

EDITOR IN CHIEF: Dulce Aparecida Brarbosa ASSOCIATE EDITOR: Dalvani Marques

Submission: $10-24-2017$

Approval: 08-08-2018

\section{ABSTRACT}

Objective: To analyze the overall critical thinking and the development of each of the cognitive skills or attributes that compose it in students of the undergraduate program in nursing through the creation of concept maps in two Brazilian teaching institutions. Method: Before-and-after experimental study, randomized, performed in two universities of two Brazilian regions, with a sample of 21 subjects at the A school and 56 at the B school. Data were collected through sociodemographic questionnaire and the California Critical Thinking Skills Test. Intervention consisted in the creation of four concept maps. Results: Scores measured for overall critical thinking do not differed between the groups of both schools; however, positive aspects among them were found for skills of evaluation, induction, and inference. Conclusion: We perceived validity as a facilitating teaching strategy of the use of concept maps in several aspects.

Descriptors: Thinking; Nursing; Learning; Educational Technology; Health Care to Prolong Life.

\section{RESUMO}

Objetivo: Analisar os níveis de pensamento crítico geral e o desenvolvimento de cada uma das habilidades ou atributos cognitivos que o compõem em estudantes do curso de graduação em Enfermagem por meio da construção de mapas conceituais em duas instituições brasileiras de ensino. Método: Estudo experimental, randomizado, tipo antes e depois, realizado em duas instituições de ensino de duas regiões brasileiras, com amostra de 21 sujeitos na escola A e 56 na B. Os dados foram coletados mediante o questionário sóciodemográfico e o California Critical Thinking Skills Test. A intervenção consistiu na construção de quatro mapas conceituais. Resultados: Os escores medidos para o pensamento crítico geral não diferiram entre os grupos de ambas escolas, entretanto, aspectos positivos entre eles foram encontrados para as habilidades de avaliação, indução e inferência. Conclusão: Foi percebida a validade enquanto estratégia de ensino facilitadora do uso dos mapas conceituais em diversos aspectos.

Descritores: Pensamento; Enfermagem; Aprendizagem; Tecnologia Educacional; Cuidados para Prolongar a Vida.

\section{RESUMEN}

Objetivo: Evaluar los niveles de pensamiento crítico general y el desarrollo de cada una de las habilidades o atributos cognitivos que lo componen de los estudiantes del grado en Enfermería, mediante la elaboración de mapas conceptuales en dos instituciones brasileñas de enseñanza. Método: Estudio experimental, aleatorizado, del tipo antes y después, realizado en dos instituciones de enseñanza de dos regiones brasileñas, con una muestra de 21 sujetos en la escuela A y 56 en la B. La recolección de datos se hizo mediante el cuestionario sociodemográfico y el estudio California Critical Thinking Skills Test. La intervención consistió en la elaboración de cuatro mapas conceptuales. Resultados: Las puntuaciones medidas para el pensamiento crítico general no difirieron entre los grupos de ambas escuelas, sin embargo, los aspectos positivos entre ellos fueron encontrados en las habilidades de evaluación, de inducción y de inferencia. Conclusión: Se reveló válido el uso de los mapas conceptuales en diversos aspectos como una estrategia de enseñanza facilitadora. Descriptores: Pensamiento; Enfermería; Aprendizaje; Tecnología Educacional; Cuidados para Prolongación de la Vida. 


\section{INTRODUCTION}

As a result of the expansion of nursing actions in the provision of health care, nurses are expected to be, increasingly, critical thinkers and autonomous learners, able to think quickly, in addition to anticipating the results in seconds, since this might result in life or death for some patients. Thus, the ability to critically think in complex situations becomes a great challenge in the education of nursing students for ensuring success during and after their training ${ }^{(1)}$.

Within this context, nursing educators should promote and encourage critical thinking (CT) through several scenarios in such a way to ensure such skills, in addition to being responsible for guaranteeing the necessary skills for its development ${ }^{(1)}$.

The Brazilian curriculum guidelines for the undergraduate education in nursing regulate the programs and features a profile of alumni with generalist, humanist, critical, and reflective characteristics, based on scientific and intellectual rigor and on ethical principles ${ }^{(2)}$. Hence, educators are responsible for training strong, independent, analytical, and reflective thinkers for practicing the profession ${ }^{(1)}$.

At this point, educators face the issue of measuring the critical thinking developed or under development by students, since, in most cases, they have no tools or more-detailed guidelines for guiding definitions and concepts about thought, criticality, and reflectivity in their daily life.

The syllabus of undergraduate programs is designed to educate future nursing professionals, and must contemplate a careful selection of relevant contents as well as teaching strategies and appropriate methods. In this organization, some limitations are identified such as the emphasis on learning outcomes with little or no attention given to the approaches used by the students in their learning process ${ }^{(3)}$.

Among the various teaching strategies studied for promoting the development of $\mathrm{CT}$, the concept map (CM) is supported by the theory of meaningful learning and helps students to organize their knowledge through graphic maps. It consists in an active teaching strategy that helps nurses and educators in the development of CT skills and problem solving on the part of students ${ }^{(4)}$.

Nursing educators should promote and encourage the development of $\mathrm{CT}$ skills both in complex and simple healthcare situations, since the practice of CT by several teaching strategies in different scenarios ensures competence and success in the professional assistance ${ }^{(1)}$.

The CT dimensions include elements that configure the cognitive skills and mind habits. In addition to these dimensions, we highlight the behavioral or emotional skills, characterized by behaviors concerning the social and humanistic conscious effort, or the involvement of the critical thinker with the individual and situation being evaluated ${ }^{(5)}$.

The skills or cognitive attributes of the CT are: analysis, defined as the recognition of claims, questions, descriptions, judgments, and information about the event; evaluation, which is the verification of the reliability of the gathered information; inference, which refers to the identification of elements required to reach conclusions; induction and deduction, which are the explanations of the outcomes when report the method used and presenting the reasoning of the convincing arguments, whether in uncertain circumstances or not ${ }^{(6)}$.

\section{OBJECTIVE}

To analyze the overall critical thinking and the development of each of the cognitive skills or attributes that compose it in students of the undergraduate program in nursing in two Brazilian teaching institutions through the creation of concept maps.

\section{METHOD}

\section{Ethical aspects}

This study was submitted to the analysis of the Research Ethics Committee, in accordance with Resolution no. 466/2012 of the National Health Council (CNS) of the Brazilian Ministry of Health, which deals with research on humans; having been approved in its ethical and methodological aspects with a favorable opinion.

\section{Study design, location, and period}

This is a quantitative study of experimental design, randomized, of before-and-after type, held in two public institutions of higher education located in different Brazilian regions, one in the Northeast and another in the Southern regions. In order to make the research feasible, we conducted a university extension course in both institutions on Advanced Cardiac Life Support (ACLS), since it is a content inherent in the training of the professional nurse, with duration of five weeks, and held between October 2015 and May 2016.

\section{Population and sample}

The study population was composed of students of undergraduate programs in nursing, bachelor's degree, offered by the two analyzed universities. We adopted as inclusion criterion those enrolled from the terms which had already offered the syllabus on the topic, which were students from the sixth term at both schools, since, in this way, all subjects would have the basic knowledge required for the development of their training. Thus, in both courses there were about 200 students who attended the first inclusion criteria for composing the sample.

The process of obtaining the sample was nonprobability sampling, with voluntary participation, and by conglomerates, according to the term in which students were enrolled at the time of composition of the participants and with those who showed interest in participating in the research.

Hence, the final sample was composed of 77 students, between the sixth and ninth terms of undergraduate programs in nursing, of which 21 participants were from the school $A$ and 56 from the school B. All were randomized with adoption of the same criteria for equating the groups, considering the variables sex, age, term of the program in which they were enrolled, nature of the school in which they graduated from high school, existence of employment bond concomitant to the training, and marital status. Thus, the school A had 12 subjects in the control group (CG) and 9 in the experimental group (EG); on the other hand, school B had 26 subjects in CG and 30 in EG. 


\section{Study protocol}

An extension course was organized with course load of 60 hours, distributed in nine on-site meetings and composed of dialogic and expository theoretical activities and laboratory simulations of practical skills mediated by clinical cases previously prepared and adjusted by the team of researchers. The necessary material and human resources were made available in a similar way in both institutions.

Data were collected by filling out a sociodemographic questionnaire before the beginning of the course and the resolution of the California Critical Thinking Skills Test (CCTST) for measuring the overall CT. This test is idiomatically available, translated, and validated, contains 34 multiple-choice questions, and is marketed by Insight Assessment, which provides assistance to researchers regarding the use and analysis of results.

According to the CCTST manual (2016), CT is classified as superior, strong, moderate, weak, or not expressed. The overall superior CT with score between 24 and 34 right answers indicates skill higher than that of the most tested. Skills at the superior level are consistent with the potential for a more advanced learning and leadership.

The overall strong CT (19-23) is consistent with the potential for academic success and career development. On the other hand, overall moderate CT (13-18) indicates the ability of challenges related to skills when involved in problem solving and decisionmaking associated with reflective learning. An overall weak CT (8-12) is a result predictive of difficulties with educational and job-related demands of reflective problems solving and reflective decision-making. On the other hand, overall not expressed $\mathrm{CT}(0-7)$ consists in the failure of the evaluated individual, with obvious cognitive fatigue or possible problems of reading or language comprehension ${ }^{(6)}$.

Intervention consisted in the creation of four concept maps (CM) on the part of students from the EG. The maps were created with the use of the Cmap Tools software, available in Portuguese language and of free access. Before the beginning of the course, there was an on-site moment with students to address the definition of CM and discuss how to create them, as well as the use of the same software when a tutorial has been developed by researchers and provided to the subjects of the research.

Throughout the extension course, students had, sequentially and independently, four opportunities for creating a CM from guiding issues related to the theme under discussion; however, on contents covered in the course. The themes were previously selected, namely: the first CM was created based on aspects of "teamwork" and "basic life support" (BLS); the second CM had as theme the approach "BLS and the introduction to advanced life support" (ALS); in the third CM we approached the in-depth analysis of the "cardiac assessment in $A L S$ " and the "treatments for cardiopulmonary arrest (PCR)"; the fourth CM involved the "total approach for an assessment on ACLS," including the post-PCR care measures.

The created CM were discussed and shared between the subjects of the research and researchers as an instrument for improving knowledge, and not just as an evaluation of concepts, since the mapping of concepts enables students to understand misconceptions and then improve their performances ${ }^{(4)}$.

\section{Analysis of results}

We used inferential descriptive statistics for analyzing data and testing the suggested hypothesis. Socioeconomic data and results of the CT scores were compiled into a spreadsheet in the statistical program SPSS ${ }^{\circledR}$ version 20.0 , encoded for their respective analyses, and disclosed in the form of tables and graphs.

Regarding the CCTST used in this study, following the closure of data collection, we sent them to the United States of American for the Insight Assessment, responsible for the descriptive analysis on the overall score of CT and its respective skills or cognitive/ partial attributes.

\section{RESULTS}

Study participants of the two institutions were mostly women, with similar averages $(A=20.71$ and $B=22.12)$. The most significant difference between the students of the institutions referred to the nature of high school in which they graduated from, and school $A$ had the most participants coming from public schools, and institution B, from private schools. Therefore, we observe that high school students from Southern schools of the country have access to federal public higher education, which was not the case with most of the subjects from the Northeast region. However, we could carry out an adequate randomization between the groups, since we perceived a uniformity of characteristics for both groups.

In Table 1 we present the averages for overall CT and of each skill or cognitive attribute for both schools based on the scores obtained with the CCTST and comparisons of means obtained with the Student's t-test for paired samples. Statistically, scores for the intervention with CM showed no significant difference ( $p$-value $=0.05$ ) for students of the EG in any of the two schools.

The results of the analysis showed that, in institution $A$, the evaluation skill increased when comparing pre- and post-tests in both CG and EG; and, as for induction, only the CG presented a slight increase.

On the other hand, in institution $B$, when verifying the values of pre- and post-tests for the CG and EG, the evaluation skill increased in the EG with statistical significance $(p=0.037)$; inference had a slight increase for the CG; induction increased only in the EG; and deduction increased in both groups in the post-test results, but without statistical significance.

Table 1 - Averages of overall critical thinking and of each skill or cognitive attribute of nursing students of the courses in schools A and B, Natal, Rio Grande do Norte, Brazil, 2017 ( $\mathrm{N}=77$ )

\begin{tabular}{lcccc}
\hline \multirow{2}{*}{ Groups } & \multicolumn{2}{c}{ School A (n=21) } & \multicolumn{2}{c}{ School B (n=56) } \\
& CG (n=12) & EG (n=09) & CG (n=26) & EG (n=30) \\
\hline Overall CT pretest & $14.8(3.0)^{*}$ & $15.1(4.5)^{*}$ & $15(3.6)^{*}$ & $13.7(3.4)^{*}$ \\
Overall CT post-test & $13.9(3.3)^{*}$ & $14.5(4.6)^{*}$ & $14.8(4.1)^{*}$ & $14(2.9)^{*}$ \\
$t$-test & $1.143(0.277)^{* *}$ & $0.588(0.573)^{* *}$ & $0.285(0.778)^{* *}$ & $0.395(0.696)^{* *}$ \\
Analysis & \multicolumn{5}{c}{} & & \\
$\quad$ Pretest & $5.0(1.4)$ & $4.3(1.2)$ & $4.38(1.1)$ & $4.3(1.1)$ \\
$\quad \begin{array}{l}\text { Post-test } \\
t \text {-test }(p)^{* * *}\end{array}$ & $4.75(1.4)$ & $3.8(1.3)$ & $4.1(1.1)$ & $4.1(1.9)$ \\
& $0.422(0.681)$ & $0.839(0.426)$ & $0.622(0.539)$ & $1.186(0.245)$ \\
\hline
\end{tabular}

To be continued 
Table 1 (concluded)

\begin{tabular}{|c|c|c|c|c|}
\hline \multirow{2}{*}{ Groups } & \multicolumn{2}{|c|}{ School A $(n=21)$} & \multicolumn{2}{|c|}{ School B $(n=56)$} \\
\hline & CG $(n=12)$ & EG $(n=09)$ & CG $(n=26)$ & $E G(n=30)$ \\
\hline \multicolumn{5}{|l|}{ Evaluation } \\
\hline Pretest & $4.5(1.8)$ & $5.5(2.6)$ & $5.6(1.9)$ & $4.8(1.8)$ \\
\hline Post-test & $4.7(1.4)$ & $5.8(2.2)$ & $5.6(2.2)$ & $5.4(1.5)$ \\
\hline$t$-test $(p)$ & $0.540(0.600)$ & $0.894(0.397)$ & $0.166(0.870)$ & $2.192(0.037)$ \\
\hline \multicolumn{5}{|l|}{ Inference } \\
\hline Pretest & $4.5(1.7)$ & $5.2(2.2)$ & $4.9(1.8)$ & $4.4(1.8)$ \\
\hline Post-test & $4.4(1.5)$ & $3.8(1.3)$ & $5.1(2.1)$ & $4.3(1.7)$ \\
\hline$t$-test $(p)$ & $0.123(0.905)$ & $2.309(0.05)$ & $0.485(0.632)$ & $0.491(0.627)$ \\
\hline \multicolumn{5}{|l|}{ Induction } \\
\hline Pretest & $6.3(1.3)$ & $6.5(2.5)$ & $6.3(2.3)$ & $5.4(1.8)$ \\
\hline Post-test & $5.6(1.6)$ & $6.6(1.9)$ & $5.7(2.1)$ & 5.5 (1.9) \\
\hline$t$-test $(p)$ & $2.345(0.139)$ & $1.070(0.734)$ & $1.341(0.192)$ & $0.313(0.756)$ \\
\hline \multicolumn{5}{|l|}{ Deduction } \\
\hline Pretest & $6.4(1.9)$ & $7.1(2.3)$ & $7.1(2.0)$ & $6.8(2.2)$ \\
\hline Post-test & $6.6(1.8)$ & $6.6(2.6)$ & $7.6(2.2)$ & $7.0(2.1)$ \\
\hline$t$-test $(p)$ & $0.414(0.687)$ & $0.627(0.548)$ & $1.148(0.262)$ & $0.360(0.722)$ \\
\hline
\end{tabular}

Note: *Variable presented by average and standard deviation; * Result of the t-test considering $p$-value $=0.05 ;{ }^{* *}$ Student's $t$-test for paired samples and 95\% significance level; CG - control group; $E G$ - experimental group; CT-critical thinking.

Overall CT pretest

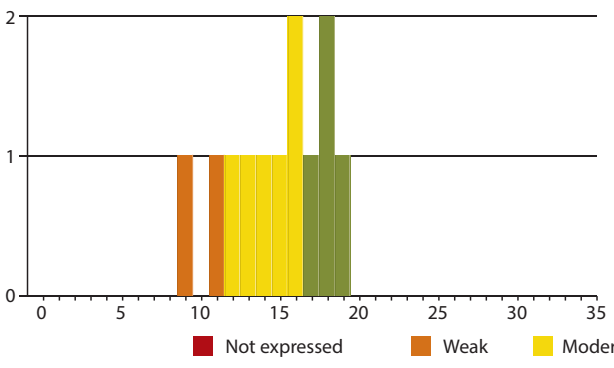

Note: CT- critical thinking.

Figure 1 - Students' overall critical thinking in the control group (CG) of school $A$ before and after the university extension course $(n=12)$

Overall CT pretest

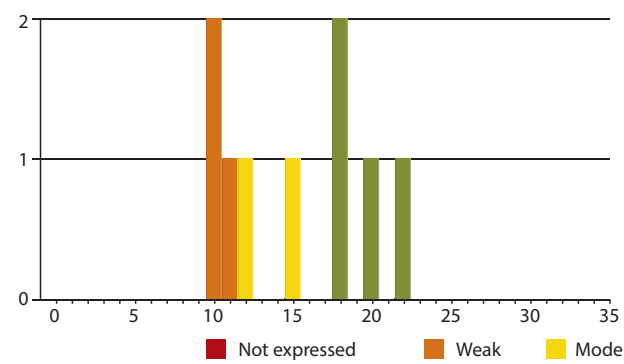

Note: CT- critical thinking

Figure 2 - Students' overall critical thinking in the experimental group (EG) of school $A$ before and after the university extension course $(n=9)$

Overall CT pretest
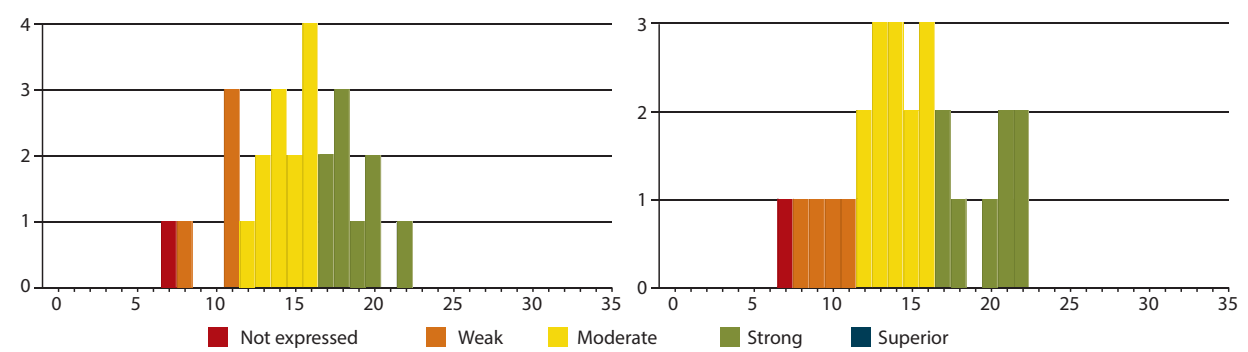

Note: $C T$ - critical thinking.

Figure 3 - Students' overall critical thinking in the control group (CG) of school B before and after the university extension course $(n=26)$
In the following figures we present charts with the categorization of the averages of the overall CT of students from the CG and EG from schools $A$ and $B$, respectively. It is worth noting that, despite all the charts pointing to discrete results in terms of increased development of overall CT, the detailed analysis points to relevant gains for use of the conducted intervention, in which the levels showed improvements.

\section{DISCUSSION}

Statistically, we found no significant differences between the control and experimental groups in the same school as well as in the comparison between students of the two analyzed institutions. The difference between schools was based only on the fact there is no student with overall CT not expressed in school A, both for the control group and the experimental group.

School A featured a practically indifferent result regarding the performance of their students in the control group before and after the extension course, which was also found among students of the experimental group. After the extension course, in both groups the non-expressed result was improved and disappeared, in the same way there was an increase in the moderate classification, mainly in students of the experimental group, which highlights the importance of CM for promoting the development of CT.

Concerning skills or cognitive attributes of CT deemed as structural elements and essential to the development of $\mathrm{CT}$, we demonstrated that the teaching strategy based on the creation of concept maps was effective.

It is noteworthy that the use of the CM strategy may guide students in such a way to help them organizing and integrating information, evaluating the existing knowledge, obtaining insights about new and prior knowledge, in addition to relating basic concepts for clinical presentations of patients. CT is one of the aspects that should be considered as a focus on future educational practices involving the creation of $\mathrm{CM}$, because the materials prepared by students still fall short in terms of thematic deepening and reflection, skill that may, possibly, be increased through the development of the $C \mathrm{~T}^{(7-8)}$.

The performance of students in the learning process can be influenced by how concept maps are implemented, from their inclusion 
Overall CT pretest

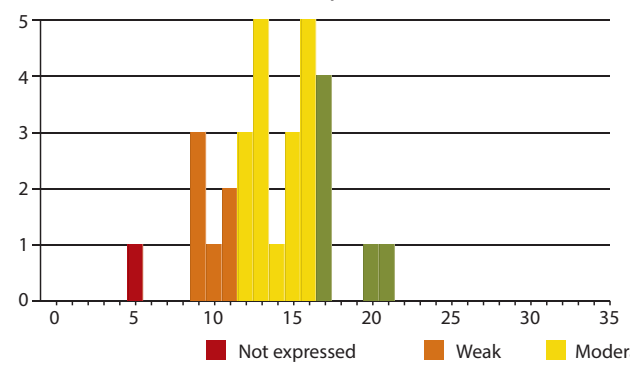

Overall CT post-test

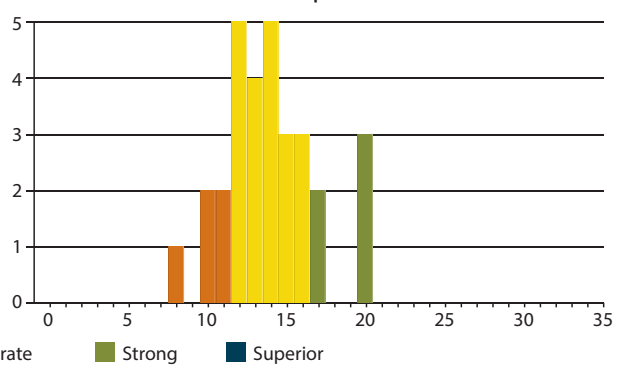

Note: CT- critical thinking

Figure 4 - Students' overall critical thinking in the experimental group (EG) of school $B$ before and after the university extension course $(n=30)$

in the process to their assessment. There are many challenges in this implementation, such as limited course load, shortage of teachers, and knowledge about this teaching strategy.

Authors of previous studies indicate that the cognitive improvement of CT skills would not happen in one term of teaching, but during a longer period of time, and the results may be related to the mapping of concepts. When creating $\mathrm{CM}$, students need to have logical conclusions or known premises of concrete knowledge through an inference process, such as identify the main concepts, determine the relationships between concepts, and propose links before reaching the conclusions $s^{(9-10)}$.

In Brazil, the undergraduate programs in nursing have their syllabus structured for a completion period between 4 and 5 years of duration. Students who composed the study sample, from both surveyed institutions, were enrolled in programs with similar syllabus structures and both with 4, 5 years of duration. From the obtained characteristics, we observed that students from institution A were enrolled in the seventh term or fourth year of the program, mostly, whereas most of the students from institution B were in the sixth term of the course, which is equivalent to the third year. Maybe this variable points to the difference obtained for the skills of inference and induction in institution $A$, in both groups.

These data corroborate a study conducted in Australia on undergraduate students in nursing, in which predictive variables were evaluated for the development of CT skills, when the study seriation was positively related to most domains. Students who were in the third and last year were the most susceptible to higher levels of $\mathrm{CT}$ and higher scores for the skills inference, evaluation, induction, and deduction ${ }^{(11)}$.

Authors of another study conducted in Iran on students of the undergraduate program in nursing measured the CT score and its skills among the freshmen and senior year students, and they found no significant association between demographic data and $\mathrm{CT}$, obtaining results considered of low level ${ }^{(12)}$.

It worth highlighting that CT skills are frequently assessed in surveys on nursing after a teaching intervention, with relative success and limited. However, we know that $C T$ is developed over time, therefore, the intervention duration consists is an important educational and research consideration ${ }^{(13)}$.

Hence, it is noteworthy that CT can be learned and improved during the professional training, and the variety of studies we found demonstrates the great concern of nursing with the theme. These studies indicate that there is much to be done regarding a consensus on $\mathrm{CT}$, teaching strategies, and training of instructors to mediate this knowledge.

This highlights the need for rethinking the issue with trade associations, such as the Brazilian Nursing Association and the Federal and Regional Councils of Nursing as well as with public and private higher education institutions ${ }^{(14)}$.

An educational intervention with the use of the CM strategy applied to nursing students of the first year obtained higher scores for the experimental group, which had eight opportunities for creating $\mathrm{CM}$. Authors of the study concluded that the strategy effectively contributes to the learning process of students, and there has been a gradual improvement in the complexity of the maps to the extent they were being created as well as a better use of theoretical knowledge regarding nursing interventions ${ }^{(3)}$.

Studies also focused on the use and potential of the CM strategy as an interactive approach focused on evaluation, planning, and development in nursing education. Moreover, researchers understand that undergraduate students are adults, have the ability to develop skills, and should be encouraged to develop a disciplined mind involving $\mathrm{CT}$ features. Within this context, fostering the ability to critically think should involve planning and implementation of strategies over the syllabus of nursing programs $s^{(15-16)}$.

It is believed that, for students to reach a level of abstraction that evidences the $\mathrm{CT}$, a longer and lasting process is needed, in such a way to instigate them to achieve such degrees of knowledge construction. The constructive proposal that guides the implementation of activities for $\mathrm{CM}$ creation promotes the facilitation of learning, and not the content-based teaching ${ }^{(7,9)}$.

These findings demonstrate that the academic level, the content of the theoretical and practical courses, and the experience acquired in clinical work contribute to the development of CT skills ${ }^{(17)}$.

\section{Study limitations}

The main limitation we found in the development of the study was the short time for intervention, which consisted in five weeks since it was associated with the writing of a doctoral dissertation.

\section{Contributions to the field of nursing}

Brazilian undergraduate programs in nursing have, in most cases, about five years for the development of $\mathrm{CT}$, and it was surprising the improvement mentioned concerning some CT levels after a very short period of time compared with the whole education nurses receive.

Within this context, we should consider the nature of the offered program, which, when considering all the skills or cognitive attributes that compose the $\mathrm{CT}$, allows us to verify that the development of such skills requires different methods, since we 
cannot always learn how to analyze, evaluate, infer, induce, and deduce if not by different pedagogical approaches and the most completed ones as possible.

\section{CONCLUSION}

Our results show a positive assessment concerning the use of concept maps for promoting CT skills in students of undergraduate programs in nursing, since there was a significant increase in skills in participants from both institutions.

The methodological design of our study generated results of great importance for the nursing field in Brazil, especially when evaluating two public higher education institutions in different regions of the country, since changes in the syllabus of undergraduate programs in nursing have been discussed for years, in order to improve the teaching and educate critical and reflective nurses able to act in the current complex labor market. However, when assessing students regarding the level of $C T$, we found overall values from moderate to strong. This study, despite having as limiting factor the duration period of the experiment, makes us aware of situations that require attention concerning the training of nurses.

Therefore, we suggest other similar studies to be carried out, preferably with longitudinal designs, in order to promote a more in-depth and longer analysis of the education process of CT in nursing students, in addition to a review of the syllabus and improvement of teachers to include in their programs teaching strategies that encourage the development of CT and facilitate the learning process of students.

\section{REFERENCES}

1. Colln-Appling CV, Giuliano D. A concept analysis of critical thinking: a guide for nurse educators. Nurse Educ Today. 2017;49:106-9. doi: 10.1016/j.nedt.2016.11.007

2. Ministério da Educação (BR). Conselho Nacional de Educação e da Câmara de Educação Superior. Resolução no 3, de 7 de novembro de 2001. Institui diretrizes curriculares nacionais do curso de graduação em Enfermagem [Internet]. Brasília; 2001 [cited 2017 Jun 10]. Available from: http://portal.mec.gov.br/cne/arquivos/pdf/CES03.pdf

3. Jaafarpou M, Aazami S, Mozafari M. Does concept mapping enhance learning outcome of nursing students? Nurse Educ Today. 2016;36:12932. doi: 10.1016/j.nedt.2015.08.029

4. Zadeh NR, Gandomani HS, Delaram M, Yekta ZP. Comparing the effect of concept mapping and conventional methods on nursing students' practical skill score. J Nurse Midwifery. 2015; 4(3):e27471. doi: 10.17795/nmsjournal27471

5. Crossetti MGO, Bittencourt GKGD, Lima AAA, Góes MGO, Saurin G. Structural elements of critical thinking of nurses in emergency care. Rev Gaucha Enferm. 2014;35(3):55-60. doi: 10.1590/1983-1447.2014.03.45947

6. California Critical Thinking Skills Test. User manual and resource guide. San Jose: California Academic Press; 2016.

7. Cogo ALP, Pedro ENR, Silva APSS, Specht AM. Evaluation of concept maps developed by nursing students with software support. Texto Contexto Enferm. 2009;18(3):482-8. doi: 10.1590/S0104-07072009000300011

8. Carvalho DPSRP, Vitor AF, Barichello E, Villar RLA, Santos VEP, Ferreira Jr MA. Aplicação do mapa conceitual: resultados com diferentes métodos de ensino-aprendizagem. Aquichan. 2016;16(3):382-91. doi: 10.5294/aqui.2016.16.3.9

9. Lee W, Chiang CH, Liao IC, Lee ML, Chen SL, Liang T. The longitudinal effect of concept map teaching on critical thinking of nursing students. Nurse Educ Today. 2013;33(10):1219-23. doi: 10.1016/j.nedt.2012.06.010

10. Kaya H, Senyuva E, Bodur G. Developing critical thinking disposition and emotional intelligence of nursing students: a longitudinal research. Nurse Educ Today. 2017;48:72-7. doi: 10.1016/j.nedt.2016.09.011

11. Hunter S, Pitt V, Croce N, Roche J. Critical thinking skills of undergraduate nursing students: description and demographic predictors. Nurse Educ Today. 2014;34(5):809-14. doi: 10.1016/j.nedt.2013.08.005

12. Azizi-Fini I, Hajibagheri A, Adib-Hajbaghery M. Critical thinking skills in nursing students: a comparison between freshmen and senior students. J Nurse Midwifery [Internet]. 2015 [cited 2017 Jun 20];4(1):e25721. Available from: https://www.ncbi.nlm.nih.gov/pmc/articles/ PMC4377532/

13. Carter AG, Creedy D, Sidebotham M. Efficacy of teaching methods used to develop critical thinking in nursing and midwifery undergraduate students: a systematic review of the literature. Nurse Educ Today. 2016;40:209-18. doi: 10.1016/j.nedt.2016.03.010

14. Alves E, Dessunti EM, Oliveira MAC. Theory basis for critical thinking in nursing and tools to implemente it: a comprehensive review. Rev Iberoam Educ Invest Enferm [Internet]. 2014 [cited 2017 Jun 20];4(2):63-74. Available from: http://www.enfermeria21.com/revistas/aladefe/ articulo/122/

15. Burrell LA. Integrating critical thinking strategies into nursing curricula. Teach Learn Nurs. 2014;9(2):52-8. doi: 10.1016/j.teln.2013.12.005

16. Hagell P, Edfors E, Hedin G, Westergren A, Hammarlund CS. Group concept mapping for evaluation and development in nursing education. Nurse Educ Today. 2016;20:147-53. doi: 10.1016/j.nepr.2016.08.006

17. Gholami M, Moghadam PK, Morammadipoor F, Tarahi MJ, Sak M, Toulabi T, et al. Comparing the effects of problem-based learning and the traditional lecture method on critical thinking skills and metacognitive awareness in nursing students in a critical care nursing course. Nurse Educ Today. 2016;45:16-21. doi: 10.1016/j.nedt.2016.06.007 